4

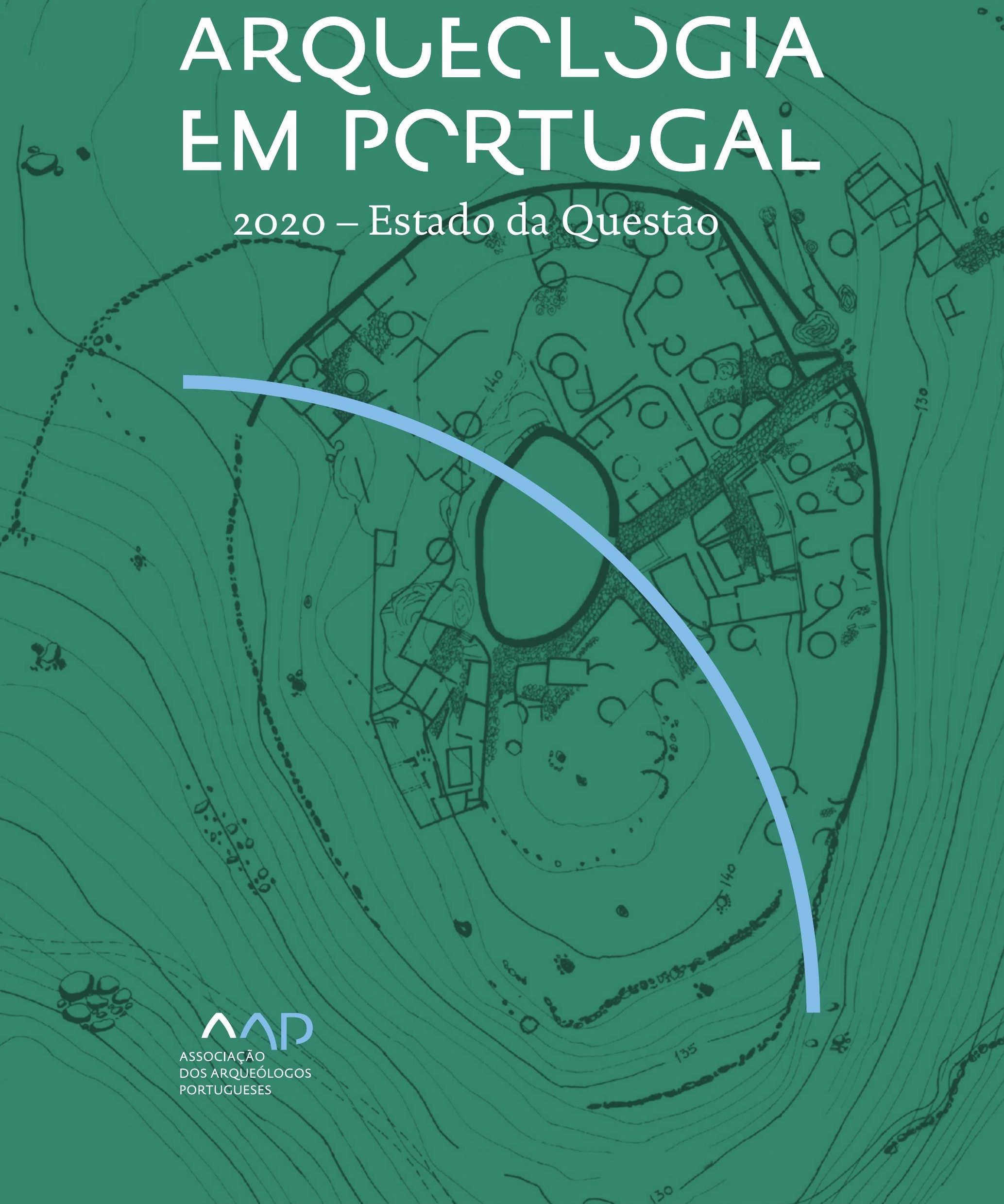


Coordenação editorial: José Morais Arnaud, César Neves e Andrea Martins Design gráfico: Flatland Design

AAP - ISBN: 978-972-9451-89-8

CITCEM - ISBN: 978-989-8970-25-1

Associação dos Arqueólogos Portugueses e CITCEM

Lisboa, 2020

O conteúdo dos artigos é da inteira responsabilidade dos autores. Sendo assim a Associação dos Arqueólogos Portugueses declina qualquer responsabilidade por eventuais equívocos ou questões de ordem ética e legal.

Desenho de capa:

Planta do castro de Monte Mozinho (Museu Municipal de Penafiel).

\section{$\hat{\wedge} \mathrm{P}$}

DOS ARQUEÓLOGOS PORTUGUESES

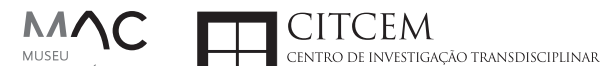
MUSEU
ARQUELLÓGICO
DO CARMO
U.PORTO

FLUP FACULDADE DE LETRAS
UNIVERSIDADE DO PORTO

Apoio

EC para a Ciência 


\section{Índice}

15 Prefácio

José Morais Arnaud

\section{Historiografia e Teoria}

17 Território, comunidade, memória e emoção: a contribuição da história da arqueologia (algumas primeiras e breves reflexões)

Ana Cristina Martins

25 Como descolonizar a arqueologia portuguesa?

Rui Gomes Coelho

41 Arqueologia e Modernidade: uma revisitação pessoal e breve de alguns aspetos da obra homónima de Julian Thomas de 2004

Vítor Oliveira Jorge

57 Dados para a História das Mulheres na Arqueologia portuguesa, dos finais do século XIX aos inícios do século XX: números, nomes e tabelas

Filipa Dimas / Mariana Diniz

73 Retractos da arqueologia portuguesa na imprensa: (in)visibilidades no feminino

Catarina Costeira / Elsa Luís

85 Arqueologia e Arqueólogos no Norte de Portugal Jacinta Bugalhão

101 Vieira Guimarães (1864-1939) e a arqueologia em Tomar: uma abordagem sobre o território e as gentes

João Amendoeira Peixoto / Ana Cristina Martins

115 Os memoráveis? A arqueologia algarvia na imprensa nacional e regional na presente centúria (2001-2019): características, visões do(s) passado(s) e a arqueologia

enquanto marca

Frederico Agosto / João Silva

129 A Evolução da Arqueologia Urbana e a Valorização Patrimonial no Barlavento Algarvio: Os casos de Portimão e Silves

Artur Mateus / Diogo Varandas / Rafael Boavida

\section{Gestão, Valorização e Salvaguarda do Património}

145 O Caderno Reivindicativo e as condições de trabalho em Arqueologia Miguel Rocha / Liliana Matias Carvalho / Regis Barbosa / Mauro Correia / Sara Simões / Jacinta Bugalhão / Sara Brito / Liliana Veríssimo Carvalho / Richard Peace / Pedro Peça / Cézer Santos

155 Os Estudos de Impacte Patrimonial como elemento para uma estratégia sustentável de minimização de impactes no âmbito de reconversões agrícolas Tiago do Pereiro

165 Salvaguarda de Património arqueológico em operações florestais: gestão e sensibilização Filipa Bragança / Gertrudes Zambujo / Sandra Lourenço / Belém Paiva / Carlos Banha / Frederico Tatá Regala / Helena Moura / Jacinta Bugalhão / João Marques / José Correia / Pedro Faria / Samuel Melro

179 Os valores do Património: uma investigação sobre os Sítios Pré-históricos de Arte Rupestre do Vale do Rio Côa e de Siega Verde José Paulo Francisco 
189 Conjugando recursos arqueológicos e naturais para potenciar as visitas ao Geoparque Litoral de Viana do Castelo (Noroeste de Portugal)

Hugo A. Sampaio / Ana M.S. Bettencourt / Susana Marinho / Ricardo Carvalhido

203 Áreas de Potencial Arqueológico na Região do Médio Tejo: Modelo Espacial Preditivo Rita Ferreira Anastácio / Ana Filipa Martins / Luiz Oosterbeek

223 Património Arqueológico e Gestão Territorial: O contributo da Arqueologia para a revisão do PDM de Avis

Ana Cristina Ribeiro

237 A coleção arqueológica do extinto Museu Municipal do Porto - Origens, Percursos e Estudos

Sónia Couto

251 Valpaços - uma nova carta arqueológica

Pedro Pereira / Maria de Fátima Casares Machado

263 Arqueologia na Cidade de Peniche

Adriano Constantino / Luís Rendeiro

273 Arqueologia Urbana: a cidade de Lagos como caso de Estudo Cátia Neto

285 Estratégias de promoção do património cultural subaquático nos Açores. O caso da ilha do Faial

José Luís Neto / José Bettencourt / Luís Borges / Pedro Parreira

297 Carta Arqueológica da Cidade Velha: Uma primeira abordagem

Jaylson Monteiro / Nireide Tavares / Sara da Veiga / Claudino Ramos / Edson Brito /

Carlos Carvalho / Francisco Moreira / Adalberto Tavares

311 Antropologia Virtual: novas metodologias para a análise morfológica e funcional Ricardo Miguel Godinho / Célia Gonçalves

\section{Didáctica da Arqueologia}

327 Como os projetos de Arqueologia podem contribuir para uma comunidade culturalmente mais consciente Alexandra Figueiredo / Claúdio Monteiro / Adolfo Silveira / Ricardo Lopes

337 Educação Patrimonial - Um cidadão esclarecido é um cidadão ativo! Ana Paula Almeida

351 A aproximação da Arqueologia à sala de aula: um caso de estudo no $3^{\circ}$ ciclo do Ensino Básico Luís Serrão Gil

363 Arqueologia 3.o - Pensar e comunicar a Arqueologia para um futuro sustentável Mónica Rolo

377 “Conversa de Arqueólogos" - Divulgar a Arqueologia em tempos de Pandemia Diogo Teixeira Dias

389 Escola Profissional de Arqueologia: desafios e oportunidades Susana Nunes / Dulcineia Pinto / Júlia Silva / Ana Mascarenhas

399 Os Museus de Arqueologia e os Jovens: a oferta educativa para o público adolescente Beatriz Correia Barata / Leonor Medeiros

411 O museu universitário como mediador entre a ciência e a sociedade: o exemplo da secção de arqueologia no Museu de História Natural e da Ciência da Universidade do Porto (MHNC-UP)

Rita Gaspar 
421 Museu de Lanifícios: Real Fábrica de Panos. Atividades no âmbito da Arqueologia Beatriz Correia Barata / Rita Salvado

427 Arqueologia Pública e o caso da localidade da Mata (Torres Novas) Cláudia Manso / Ana Rita Ferreira / Cristiana Ferreira / Vanessa Cardoso Antunes

431 Do sítio arqueológico ao museu: um percurso (também) didático Lídia Fernandes

447 Estão todos convidados para a Festa! E para dançar também... O projecto do Serviço Educativo do Museu Arqueológico do Carmo na $5^{\underline{a}}$ Edição da Festa da Arqueologia Rita Pires dos Santos

459 O “Clã de Carenque”, um projeto didático de arqueologia Eduardo Gonzalez Rocha

469 Mediação cultural: peixe que puxa carroça nas Ruínas Romanas de Troia Inês Vaz Pinto / Ana Patrícia Magalhães / Patrícia Brum / Filipa Santos

481 Didática Arqueológica, experiências do Projeto Mértola Vila Museu Maria de Fátima Palma / Clara Rodrigues / Susana Gómez / Lígia Rafael

\section{Arte Rupestre}

497 Os inventários de arte rupestre em Portugal Mila Simões de Abreu

513 O projeto FIRST-ART - conservação, documentação e gestão das primeiras manifestações de arte rupestre no Sudoeste da Península Ibérica: as grutas do Escoural e Maltravieso Sara Garcês / Hipólito Collado / José Julio García Arranz / Luiz Oosterbeek / António Carlos Silva / Pierluigi Rosina / Hugo Gomes / Anabela Borralheiro Pereira / George Nash / Esmeralda Gomes / Nelson Almeida / Carlos Carpetudo

523 Trabalhos de documentação de arte paleolítica realizados no âmbito do projeto PalæoCôa André Tomás Santos / António Fernando Barbosa / Luís Luís / Marcelo Silvestre / Thierry Aubry

537 Imagens fantasmagóricas, silhuetas elusivas: as figuras humanas na arte do Paleolítico Superior da região do Côa Mário Reis

$55^{1}$ Os motivos zoomórficos representados nas placas de tear de Vila Nova de São Pedro (Azambuja, Portugal) Andrea Martins / César Neves / José M. Arnaud / Mariana Diniz

571 Arte Rupestre do Monte de Góios (Lanhelas, Caminha). Síntese dos resultados dos trabalhos efectuados em 2007-2009 Mário Varela Gomes

599 Gravuras rupestres de barquiformes no Monte de S. Romão, Guimarães, Noroeste de Portugal Daniela Cardoso

613 Círculos segmentados gravados na Bacia do Rio Lima (Noroeste de Portugal): contributos para o seu estudo Diogo Marinho / Ana M.S. Bettencourt / Hugo Aluai Sampaio

631 Equídeos gravados no curso inferior do Rio Mouro, Monção (NW Portugal). Análise preliminar Coutinho, L.M. / Bettencourt, A.M.S / Sampaio, Hugo A.S

645 Paletas na Arte Rupestre do Noroeste de Portugal. Inventário preliminar Bruna Sousa Afonso / Ana M. S. Bettencourt / Hugo A. Sampaio 


\section{Pré-História}

661 O projeto Miño/Minho: balanço de quatro anos de trabalhos arqueológicos Sérgio Monteiro-Rodrigues / João Pedro Cunha-Ribeiro / Eduardo Méndez-Quintas / Carlos Ferreira / Pedro Xavier / José Meireles / Alberto Gomes / Manuel Santonja / Alfredo Pérez-González

677 A ocupação paleolítica da margem esquerda do Baixo Minho: a indústria lítica do sítio de Pedreiras 2 (Monção, Portugal) e a sua integração no contexto regional Carlos Ferreira / João Pedro Cunha-Ribeiro / Sérgio Monteiro-Rodrigues / Eduardo Méndez-Quintas / Pedro Xavier / José Meireles / Alberto Gomes / Manuel Santonja / Alfredo Pérez-González

693 O sítio acheulense do Plistocénico médio da Gruta da Aroeira Joan Daura / Montserrat Sanz / Filipa Rodrigues / Pedro Souto / João Zilhão

703 As sociedades neandertais no Barlavento algarvio: modelos preditivos com recurso aos SIG

Daniela Maio

715 A utilização de quartzo durante o Paleolítico Superior no território dos vales dos rios Vouga e Côa

Cristina Gameiro / Thierry Aubry / Bárbara Costa / Sérgio Gomes / Luís Luís / Carmen Manzano / André Tomás Santos

733 Uma perspetiva diacrónica da ocupação do concheiro do Cabeço da Amoreira (Muge, Portugal) a partir da tecnologia lítica Joana Belmiro / João Cascalheira / Célia Gonçalves

745 Novos dados sobre a Pré-história Antiga no concelho de Palmela. A intervenção arqueológica no sítio do Poceirão I

Michelle Teixeira Santos

757 Problemas em torno de Datas Absolutas Pré-Históricas no Norte do Alentejo Jorge de Oliveira

771 Povoamento pré-histórico nas áreas montanhosas do NO de Portugal: o Abrigo 1 de Vale de Cerdeira Pedro Xavier / José Meireles / Carlos Alves

783 Apreciação do povoamento do Neolítico Inicial na Baixa Bacia do Douro. A Lavra I (Serra da Aboboreira) como caso de estudo Maria de Jesus Sanches

797 O Processo de Neolitização na Plataforma do Mondego: os dados do Sector C do Outeiro dos Castelos de Beijós (Carregal do Sal)

João Carlos de Senna-Martinez / José Manuel Quintã Ventura / Andreia Carvalho / Cíntia Maurício

823 Novos trabalhos na Lapa da Bugalheira (Almonda, Torres Novas) Filipa Rodrigues / Pedro Souto / Artur Ferreira / Alexandre Varanda / Luís Gomes / Helena Gomes / João Zilhão

837 A pedra polida e afeiçoada do sítio do Neolítico médio da Moita do Ourives (Benavente, Portugal)

César Neves

857 Casal do Outeiro (Encarnação, Mafra): novos contributos para o conhecimento do povoamento do Neolítico final na Península de Lisboa.

Cátia Delicado / Carlos Maneira e Costa / Marta Miranda / Ana Catarina Sousa

873 Stresse infantil, morbilidade e mortalidade no sítio arqueológico do Neolítico Final/ Calcolítico ( $4^{\circ}$ e $3^{\circ}$ milénio a.C.) do Monte do Carrascal 2 (Ferreira do Alentejo, Beja) Liliana Matias de Carvalho / Sofia N. Wasterlain 
885 Come together: O Conjunto Megalítico das Motas (Monção, Viana do Castelo) e as expressões Campaniformes do Alto Minho Ana Catarina Basílio / Rui Ramos

899 Trabalhos arqueológicos no sítio Calcolítico da Pedreira do Poio Carla Magalhães / João Muralha / Mário Reis / António Batarda Fernandes

913 O sítio arqueológico de Castanheiro do Vento. Da arquitectura do sítio à arquitectura de um território João Muralha Cardoso

925 Estudo zooarqueológico das faunas do Calcolítico final de Vila Nova de São Pedro (Azambuja, Portugal): Campanhas de 2017 e 2018 Cleia Detry / Ana Catarina Francisco / Mariana Diniz / Andrea Martins / César Neves / José Morais Arnaud

943 As faunas depositadas no Museu Arqueológico do Carmo provenientes de Vila Nova de São Pedro (Azambuja): as campanhas de 1937 a 1967 Ana Catarina Francisco / Cleia Detry / César Neves / Andrea Martins / Mariana Diniz / José Morais Arnaud

959 Análise funcional de material lítico em sílex do castro de Vila Nova de S. Pedro (Azambuja, Portugal): uma primeira abordagem Rafael Lima

971 O recinto da Folha do Ouro 1 (Serpa) no contexto dos recintos de fossos calcolíticos alentejanos

António Carlos Valera / Tiago do Pereiro / Pedro Valério / António M. Monge Soares

\section{Proto-História}

987 Produção de sal marinho na Idade do Bronze do noroeste Português. Alguns dados para uma reflexão

Ana M. S. Bettencourt / Sara Luz / Nuno Oliveira / Pedro P. Simões / Maria Isabel C. Alves / Emílio Abad-Vidal

1001 A estátua-menir do Pedrão ou de São Bartolomeu do Mar (Esposende, noroeste de Portugal) no contexto arqueológico da fachada costeira de entre os rios Neiva e Cávado Ana M. S. Bettencourt / Manuel Santos-Estévez / Pedro Pimenta Simões / Luís Gonçalves

1015 O Castro do Muro (Vandoma/Baltar, Paredes) - notas para uma biografia de ocupação da Idade do Bronze à Idade Média

Maria Antónia D. Silva / Ana M. S. Bettencourt / António Manuel S. P. Silva / Natália Félix

1031 Do Bronze Final à Idade Média - continuidades e hiatos na ocupação de Povoados em Oliveira de Azeméis João Tiago Tavares / Adriaan de Man

1041 As faunas do final da Idade do Bronze no Sul de Portugal: leituras desde o Outeiro do Circo (Beja)

Nelson J. Almeida / Íris Dias / Cleia Detry / Eduardo Porfírio / Miguel Serra

1055 A Espada do Monte das Oliveiras (Serpa) - uma arma do Bronze Pleno do Sudoeste Rui M. G. Monge Soares / Pedro Valério / Mariana Nabais / António M. Monge Soares

1065 São Julião da Branca (Albergaria-a-Velha) - Investigação e valorização de um povoado do Bronze Final

António Manuel S. P. Silva / Paulo A. P. Lemos / Sara Almeida e Silva / Edite Martins de Sá

1083 Do castro de S. João ao Mosteiro de Santa Clara: notícia de uma intervenção arqueológica, em Vila do Conde Rui Pinheiro 
1095 O castro de Ovil (Espinho), um quarto de século de investigação - resultados e questões em aberto

Jorge Fernando Salvador / António Manuel S. P. Silva

1111 O Castro de Salreu (Estarreja), um povoado proto-histórico no litoral do Entre Douro e Vouga

Sara Almeida e Silva / António Manuel S. P. Silva / Paulo A. P. Lemos / Edite Martins de Sá

1127 Castro de Nossa Senhora das Necessidades (Sernancelhe): uma primeira análise artefactual Telma Susana O. Ribeiro

${ }_{1141}$ A cividade de Bagunte. O estado atual da investigação Pedro Brochado de Almeida

1153 Zoomorfos na cerâmica da Idade do Ferro no NW Peninsular: inventário, cronologias e significado Nuno Oliveira / Cristina Seoane

1163 Vasos gregos em Portugal: diferentes maneiras de contar a história do intercâmbio cultural na Idade do Ferro

Daniela Ferreira

1175 Os exotica da necrópole da Idade do Ferro do Olival do Senhor dos Mártires (Alcácer do Sal) no seu contexto regional

Francisco B. Gomes

\section{Antiguidade Clássica e Tardia}

1191 O uso de madeira como combustível no sítio da Quinta de Crestelos (Baixo Sabor): da Idade do Ferro à Romanização Filipe Vaz / João Tereso / Sérgio Simões Pereira / José Sastre / Javier Larrazabal Galarza / Susana Cosme / José António Pereira / Israel Espi

1207 Cultivos de Época Romana no Baixo Sabor: continuidade em tempos de mudança? João Pedro Tereso / Sérgio Simões Pereira / Filipe Santos / Luís Seabra / Filipe Vaz

1221 A casa romana na Hispânia: aplicação dos modelos itálicos nas províncias ibéricas Fernanda Magalhães / Diego Machado / Manuela Martins

1235 As pinturas murais romanas da Rua General Sousa Machado, n. ${ }^{5}$ 1, Chaves José Carvalho

1243 Trás do Castelo (Vale de Mir, Pegarinhos, Alijó) - Uma exploração agrícola romana do Douro

Tony Silvino / Pedro Pereira

1255 A sequência de ocupação no quadrante sudeste de Bracara Augusta: as transformações de uma unidade doméstica Lara Fernandes / Manuela Martins

1263 Os Mosaicos com decoração geométrica e geométrico-vegetalista dos sítios arqueológicos da área do Conuentus Bracaraugustanus. Novas abordagens quanto à conservação, restauro, decoração e datação Maria de Fátima Abraços / Licínia Wrench

1277 “Casa Romana” do Castro de São Domingos (Cristelos, Lousada): Escavação, Estudo e Musealização Paulo André de P. Lemos

1291 A arqueobotânica no Castro de Guifões (Matosinhos, Noroeste de Portugal): O primeiro estudo carpológico

Luís Seabra / Andreia Arezes / Catarina Magalhães / José Varela / João Pedro Tereso 
1305 Um Horreum Augustano na Foz do Douro (Monte do Castelo de Gaia, Vila Nova de Gaia) Rui Ramos

1311 Ponderais romanos na Lusitânia: padrões, formas, materiais e contextos de utilização Diego Barrios Rodríguez

1323 Um almofariz centro-itálico na foz do Mondego

Marco Penajoia

1335 Estruturas romanas de Carnide - Lisboa Luísa Batalha / Mário Monteiro / Guilherme Cardoso

1347 O contexto funerário do sector da "necrópole NO" da Rua das Portas de S. Antão (Lisboa): o espaço, os artefactos, os indivíduos e a sua interconectividade na interpretação do passado Sílvia Loja, José Carlos Quaresma, Nelson Cabaço, Marina Lourenço, Sílvia Casimiro, Rodrigo Banha da Silva, Francisca Alves-Cardoso

${ }_{1361}$ Povoamento em época Romana na Amadora - resultados de um projeto pluridisciplinar Gisela Encarnação / Vanessa Dias

1371 A Arquitectura Residencial em Mirobriga (Santiago do Cacém): contributo a partir de um estudo de caso Filipe Sousa / Catarina Felício

${ }_{1385}$ O fim do ciclo. Saneamento e gestão de resíduos nos edifícios termais de Mirobriga (Santiago do Cacém)

Catarina Felício / Filipe Sousa

1399 Balsa, Topografia e Urbanismo de uma Cidade Portuária Vítor Silva Dias / João Pedro Bernardes / Celso Candeias / Cristina Tété Garcia

1413 No Largo das Mouras Velhas em Faro (2017): novas evidências da necrópole norte de Ossonoba e da sua ocupação medieval Ricardo Costeira da Silva / Paulo Botelho / Fernando Santos / Liliana Nunes

1429 Instrumentos de pesca recuperados numa fábrica de salga em Ossonoba (Faro) Inês Rasteiro / Ricardo Costeira da Silva / Paulo Botelho

1439 A Necrópole Romana do Eirô, Duas Igrejas (Penafiel): intervenção arqueológica de 2016 Laura Sousa / Teresa Soeiro

1457 Ritual, descarte ou afetividade? A presença de Canis lupus familiaris na Necrópole Noroeste de Olisipo (Lisboa)

Beatriz Calapez Santos / Sofia Simões Pereira / Rodrigo Banha da Silva / Sílvia Casimiro / Cleia Detry / Francisca Alves Cardoso

1467 Dinâmicas económicas em Bracara na Antiguidade Tardia Diego Machado / Manuela Martins / Fernanda Magalhães / Natália Botica

1479 Cerâmicas e Vidros da Antiguidade Tardia do Edifício sob a Igreja do Bom Jesus (Vila Nova de Gaia) Joaquim Filipe Ramos

1493 Novos contributos para a topografia histórica de Mértola no período romano e na Antiguidade Tardia Virgílio Lopes

\section{8. Época Medieval}

1511 Cerâmicas islâmicas no Garb setentrional "português": algumas evidências e incógnitas Constança dos Santos / Helena Catarino / Susana Gómez / Maria José Gonçalves / Isabel Inácio / Gonçalo Lopes / Jacinta Bugalhão / Sandra Cavaco / Jaquelina Covaneiro / Isabel Cristina Fernandes / Ana Sofia Gomes 
1525 Contributo para o conhecimento da cosmética islâmica, em Silves, durante a Idade Média Rosa Varela Gomes

1537 Yábura e o seu território - uma análise histórico-arqueológica de Évora entre os séculos VIII-XII José Rui Santos

1547 A encosta sul do Castelo de Palmela - resultados preliminares da escavação arqueológica Luís Filipe Pereira / Michelle Teixeira Santos

1559 A igreja de São Lourenço (Mouraria, Lisboa): um conjunto de silos e de cerâmica medieval islâmica

Andreia Filipa Moreira Rodrigues

1571 O registo material de movimentações populacionais no Médio Tejo, durante os séculos XII-XIII. Dois casos de "sunken featured buildings", nos concelhos de Cartaxo e Torres Novas Marco Liberato / Helena Santos / Nuno Santos

1585 O nordeste transmontano nos alvores da Idade média. Notas para reflexão Ana Maria da Costa Oliveira

1601 Sepulturas escavadas na rocha do Norte de Portugal e do Vale do Douro: primeiros resultados do Projecto SER-NPVD

Mário Jorge Barroca / César Guedes / Andreia Arezes / Ana Maria Oliveira

1619 "Portucalem Castrum Novum" entre o Mediterrâneo e o Atlântico: o estudo dos materiais cerâmicos alto-medievais do arqueossítio da rua de D. Hugo, nํ. 5 (Porto) João Luís Veloso

1627 A Alta Idade Média na fronteira de Lafões: notas preliminares sobre a Arqueologia no Concelho de Vouzela

Manuel Luís Real / Catarina Tente

1641 Um conjunto cerâmico medieval fora de portas: um breve testemunho aveirense Susana Temudo

${ }_{1651}$ Os Lóios do Porto: uma perspetiva integrada no panorama funerário da Baixa Idade Média à Época Moderna em meios urbanos em Portugal

Ana Lema Seabra

1659 O Caminho Português Interior de Santiago como eixo viário na Idade Média Pedro Azevedo

1665 Morfologia Urbana: Um exercício em torno do Castelo de Ourém André Donas-Botto / Jaqueline Pereira

1677 Intervenção arqueológica na Rua Marquês de Pombal/Largo do Espírito Santo (Bucelas, Loures)

Florbela Estêvão / Nathalie Antunes-Ferreira / Dário Ramos Neves / Inês Lisboa

1691 O Cemitério Medieval do Poço do Borratém e a espacialidade funerária na cidade de Lisboa Inês Belém / Vanessa Filipe / Vasco Noronha Vieira / Sónia Ferro / Rodrigo Banha da Silva

1705 Um Espaço Funerário Conventual do séc. XV em Lisboa: o caso do Convento de São Domingos da Cidade Sérgio Pedroso / Sílvia Casimiro / Rodrigo Banha da Silva / Francisca Alves Cardoso

\section{9. Época Moderna e Contemporânea}

1721 Arqueologia Moderna em Portugal: algumas reflexões críticas em torno da quantificação de conjuntos cerâmicos e suas inferências históricas e antropológicas Rodrigo Banha da Silva / André Bargão / Sara da Cruz Ferreira

1733 Faianças de dois contextos entre os finais do século XVI e XVIII do Palácio dos Condes de Penafiel, Lisboa

Martim Lopes / Tomás Mesquita 
1747 Um perfil de consumo do século XVIII na foz do Tejo: O caso do Mercado da Ribeira, Lisboa Sara da Cruz Ferreira / Rodrigo Banha da Silva / André Bargão

1761 Os Cachimbos dos Séculos XVII e XVIII do Palácio Mesquitela e Convento dos Inglesinhos (Lisboa)

Inês Simão / Marina Pinto / João Pimenta / Sara da Cruz Ferreira / André Bargão / Rodrigo Banha da Silva

1775 "Tomar os fumos da erua que chamão em Portugal erua sancta». Estudo de Cachimbos provenientes da Rua do Terreiro do Trigo, Lisboa

Miguel Martins de Sousa / José Pedro Henriques / Vanessa Galiza Filipe

1787 Cachimbos de Barro Caulínitico da Sé da Cidade Velha (República de Cabo Verde)

Rodrigo Banha da Silva / João Pimenta / Clementino Amaro

1801 Algumas considerações sobre espólio não cerâmico recuperado no Largo de Jesus (Lisboa) Carlos Boavida

1815 Adereços de vidro, dos séculos XVI-XVIII, procedentes do antigo Convento de Santana de Lisboa (anéis, braceletes e contas)

Joana Gonçalves / Rosa Varela Gomes / Mário Varela Gomes

1837 Da ostentação, luxo e poder à simplicidade do uso quotidiano: arqueologia e simbologia de joias e adornos da Idade Moderna Portuguesa Jéssica Iglésias

1849 Os amuletos em Portugal - dos objetos às superstições: o coral vermelho Alexandra Vieira

1865 Cerâmicas de Vila Franca de Xira nos séculos XV e XVI Eva Pires

1879 «Não passa por teu o que me pertence». Marcas de individualização associadas a faianças do Convento de Nossa Senhora de Aracoeli, Alcácer do Sal Catarina Parreira / Íris Fragoso / Miguel Martins de Sousa

1891 Cerâmica de Leiria: alguns focos de produção

Jaqueline Pereira / André Donas-Botto

1901 Os Fornos na Rua da Biquinha, em Óbidos Hugo Silva / Filipe Oliveira

1909 A casa de Pêro Fernandes, contador dos contos de D. Manuel I: o sítio arqueológico da Silha do Alferes, Seixal (século XVI) Mariana Nunes Ferreira

1921 O Alto da Vigia (Sintra) e a vigilância e defesa da costa Alexandre Gonçalves / Sandra Santos

1937 O contexto da torre sineira da Igreja de Santa Maria de Loures Paulo Calaveira / Martim Lopes

1949 A Necrópole do Hospital Militar do Castelo de São Jorge e as práticas funerárias na Lisboa de Época Moderna Susana Henriques / Liliana Matias de Carvalho / Ana Amarante / Sofia N. Wasterlain

1963 SAND - Sarilhos Grandes Entre dois Mundos: o adro da Igreja e a Paleobiologia dos ossos humanos recuperados

Paula Alves Pereira / Roger Lee Jesus / Bruno M. Magalhães

1975 Expansão urbana da vila de Cascais no século XVII e XVIII: a intervenção arqueológica na Rua da Vitória no 15 a 17

Tiago Pereira / Vanessa Filipe

1987 Novos dados para o conhecimento do Urbanismo de Faro em época Moderna Ana Rosa 
1995 Um exemplo de Arqueologia Urbana em Alcoutim: o Antigo Edifício dos CTT Marco Fernandes / Marta Dias / Alexandra Gradim / Virgílio Lopes / Susana Gómez Martínez

2007 Palácio dos Ferrazes (Rua das Flores/Rua da Vitória, Porto): a cocheira de Domingos Oliveira Maia

Francisco Raimundo

2021 As muitas vidas de um edifício urbano: História, Arqueologia e Antropologia no antigo Recreatório Paroquial de Penafiel Helena Bernardo / Jorge Sampaio / Marta Borges

2035 O convento de Nossa Senhora da Esperança de Ponta Delgada: o contributo da arqueologia para o conhecimento de um monumento identitário João Gonçalves Araújo / N’Zinga Oliveira

2047 Arqueologia na ilha do Corvo... em busca da capela de Nossa Senhora do Rosário Tânia Manuel Casimiro / José Luís Neto / Luís Borges / Pedro Parreira

2059 Perdidos à vista da Costa. Trabalhos arqueológicos subaquáticos na Barra do Tejo Jorge Freire / José Bettencourt / Augusto Salgado

2071 Arqueologia marítima em Cabo Verde: enquadramento e primeiros resultados do projecto CONCHA

José Bettencourt / Adilson Dias / Carlos Lima / Christelle Chouzenoux / Cristóvão Fonseca / Dúnia Pereira / Gonçalo Lopes / Inês Coelho / Jaylson Monteiro / José Lima / Maria Eugénia Alves / Patrícia Carvalho / Tiago Silva

2085 Trabalhos arqueológicos na Cidade Velha (Ribeira Grande de Santiago, Cabo Verde): reflexões sobre um projecto de investigação e divulgação patrimonial André Teixeira / Jaylson Monteiro / Mariana Mateus / Nireide Tavares / Cristovão Fonseca / Gonçalo C. Lopes / Joana Bento Torres / Dúnia Pereira / André Bargão / Aurélie Mayer / Bruno Zélie / Carlos Lima / Christelle Chouzenoux / Inês Henriques / Inês Pinto Coelho / José Lima / Patrícia Carvalho / Tiago Silva

2103 A antiga fortificação de Quelba / Khor Kalba (E.A.U.). Resultados de quatro campanhas de escavações, problemáticas e perspectivas futuras Rui Carita / Rosa Varela Gomes / Mário Varela Gomes / Kamyar Kamyad

2123 Colónias para homens novos: arqueologia da colonização agrária fascista no noroeste ibérico Xurxo Ayán Vila / José Mạ . Señorán Martín 


\title{
O CONTEXTO DA TORRE SINEIRA DA IGREJA DE SANTA MARIA DE LOURES
}

\author{
Paulo Calaveira ${ }^{1}$, Martim Lopes ${ }^{2}$
}

\begin{abstract}
RESUMO
Teve lugar em 2003 uma intervenção arqueológica de emergência, por parte do município de Loures na área exterior da Igreja de Santa Maria de Loures.

Os autores procuram efetuar uma contextualização histórica deste edificado, bem como uma análise das evidências materiais exumadas e a sua relação com o contexto em que se inserem. Assim, apresentam-se os dados obtidos pelo estudo do espólio cerâmico e metálico, e a sua relação com as sepulturas e ossários que foram escavados, tendo também em consideração as relações estratigráficas existentes.

Este é um contexto de relevância para a história de Loures Medieval/Moderna, dado que a igreja desempenhará um papel crucial no desenvolvimento do traçado urbano da povoação.

Palavras-chave: Loures, Arqueologia Moderna, Cultura Material, Séculos XVI-XVIII, Câmbios espaciais.
\end{abstract}

\begin{abstract}
In 2003, an archaeological intervention, of emergence, was coordinated by the city council of Loures on the external area of the church of Santa Maria de Loures.

The authors try to make a historical contextualization of the building, forwarded by an analysis of the material evidences collected and their relation with the stratigraphy of which they are part.

Whereby are presented the results of the study of the ceramic and metallic evidences and the analysis of the stratigraphy and structures detected.

This is a context with relevance for the history of the evolution of the Medieval/Modern Loures because of the decisive paper of the church in the layout of the oldest part of the contemporary city.

Keywords: Loures, Historical Archaeology, Material Culture, XVI-XVIII centuries, Spatial changes.
\end{abstract}

\section{INTRODUÇÃO}

A Igreja de Santa Maria, Matriz de Loures, localiza-se em Loures, distrito de Lisboa. Circundada a Norte, Este e Oeste pelo rio de Loures, local caracterizado por minifúndios e habitações de caráter rural (Oliveira, 2018, p. 1).

Construída antes da segunda metade do século XIII pelos Templários sobre as ruinas de uma igreja mais antiga (Oliveira, Silva e Estêvão, 1999, p. 55), teve um vigário nomeado em 1250 por D. Ayres Vasques. Mendes Leal autor do livro Admiravel Egreja Matriz de Loures, de 1909, conseguiu consultar a documentação referente á Igreja, sendo alguma dela, à época, inédita e anterior a 1600. Essa documentação relati- vamente ao adro e envolvente da Igreja transmitiu informação importante, desde logo por assinalar o início da construção da Torre Sineira em 1620. Esta iria substituir o antigo campanário, demolido em 1625, um ano após o término da construção (Oliveira,2018, p. 2-3). Pelo facto de esta se encontrar isolada houve a construção de 6 moradias em 1626, cujo objetivo seria por um lado evitar o isolamento desta e por outro garantir o seu cuidado (Leal, 1909). Entre as décadas de 70 e 80 do século XVII existem diversas construções no local, as quais, na sua maioria não terão impacto sobre a temática deste artigo, tratando-se de 2 arrecadações e uma plantação de oliveiras no adro da Igreja. Contudo a construção da torre do relógio terá impacto, uma vez que será

1. NOVA-FCSH; paulocalaveiras@gmail.com

2. NOVA-FCSH; martimafonsorl@sapo.pt 
construída junto ao lado Este da Torre Sineira, entretanto demolida (Oliveira, 2018, p. 3).

\section{A ESCAVAÇÃO DA TORRE SINEIRA}

A escavação ocorreu em 2003 como resultado da implementação de um projeto camarário que visava a reformulação do espaço exterior da Igreja. Os trabalhos arqueológicos, inicialmente planeados enquanto intervenção de acompanhamento, ficaram a cargo do Gabinete de Arqueologia da Divisão do Património Cultural da Câmara Municipal de Loures, sob a responsabilidade da arqueóloga Ana Cristina Oliveira (Oliveira, 2018, p.5).

Durante o acompanhamento foi detetada uma estrutura quadrangular, denominada de estrutura $\mathrm{T}$, interpretada como o único testemunho preservado da torre sineira. Nessa zona foi intervencionado, quer o interior, quer o exterior da estrutura, até à cota máxima de afetação da obra, com uma profundidade total de um metro. Foram então definidas três áreas de intervenção, que seguiram a orientação proporcionada pela própria estrutura da Igreja. área A - correspondente ao interior da estrutura; área B - situada no exterior, a Norte, limitada pelo prolongamento do alinhamento exterior da torre e por área de sondagem; área $\mathrm{C}$ - faixa adjacente exterior, a Este, com um metro de largura, sendo o comprimento definido pela área B a Norte e a Sul pela parede Norte da Igreja (Oliveira, 2018, p.5).

No decorrer dos trabalhos foi detetada também uma necrópole, a qual terá pelo menos três ossários e dezassete esqueletos, nas três áreas intervencionadas. Devido a limitações relacionadas com a cota e área de afetação da obra a real dimensão da necrópole é desconhecida, tendo por essa razão a parte escavada sido considerada apenas como uma amostra da realidade arqueológica aí existente.

\section{ESTRUTURA “T”}

Estrutura formada por duas paredes uma a nascente e outra a Norte, que forma um ângulo reto. Estas tocam os silhares da parede da igreja fazendo, assim, uma estrutura quadrangular (Oliveira, 2018, p. 9). O aparelho é constituído por blocos de calcário de grande dimensão no exterior. O interior, constituído por calcários e basaltos, apresenta também alguns seixos rolados e alguns fragmentos cerâmicos, unidos por uma argamassa elaborada à base de cal
(Oliveira, 2018, p. 9). O método construtivo aqui aplicado é composto por pedras abundantes regionalmente, nomeadamente os calcários, os basaltos e os seixos rolados, dado que esta região se encontra na junção entre um maciço calcário e basáltico, tendo os seixos, muito provavelmente, ter sido recolhidos no rio de Loures.

\section{ESPÓLIO CERÂMICO}

O espólio analisado no presente estudo apresenta-se bastante fragmentado, condicionando a informação passível de ser retirada. A cerâmica comum é a melhor representada, com $69 \%$ do total recolhido. Segue-se a faiança com $14 \%$ do total exumado e os azulejos com $13 \%$. Apenas $3 \%$ dos materiais são porcelanas e $1 \%$ corresponde a cerâmica de construção, a qual não foi estudada.

Uma grande percentagem de materiais saiu da área A, com $42 \%$ do total. Isso pode dever-se a diversos fatores, um dois quais poderá estar relaçionado com os enterramentos que existem nessa área, os quais também são, numericamente, superiores em relação às outras áreas de escavação. Salientar que, do universo em análise, não se sabe a área de $42 \%$ do espólio. Da área B vem ${ }_{12} \%$ e da área C vem $4 \%$, situação que pode dever-se ao facto de ser nesta área onde foram detetadas menos sepulturas. Com menos de $1 \%$ registam-se materiais em que não é precisa a origem na área B ou C.

\subsection{Cerâmica Comum}

A cerâmica comum é a melhor representada dos materiais analisados, correspondendo a $69 \%$ do conjunto estudado. $\mathrm{O}$ que se traduz quantitativamente em 210 fragmentos e, pelo menos, 72 indivíduos, de acordo com o protocolo de Breauvray (Arcelin e Tuffreau-Libre, 1998).

Seguindo a proposta, no que respeita à função, de Jacinta Bugalhão e Inês Coelho, as cerâmicas comuns foram agrupadas em cozinha, mesa, armazenamento e transporte (Bugalhão e Coelho, 2017, p. 109).

A nível de cerâmica de cozinha foram exumados 1 alguidar, 1 bacia, 3 possíveis frigideiras, 8 panelas, e 3 que poderão ser panelas, 3 tachos, a possibilidade de haver um quarto, existindo 4 em que morfologicamente não se distingue bem entre tacho ou panela. Funcionalmente o alguidar está associado à preparação de alimentos, mas também à higiene pessoal. A frigideira era utilizada para fritar alimentos, ou 
em azeite, ou em banha animal. O tacho e a panela teriam utilizações semelhantes, contudo o tacho podia-se servir à mesa, passando a ter uma dimensão comunitária (Bugalhão e Coelho, 2017, p. 111, 120 e 130).

Nas cerâmicas de mesa destaca-se a presença de 1 possível bilha, de 4 jarrinhas, de 1 possível jarro, de 2 púcaros e um possível terceiro de 11 potinhos, havendo um décimo segundo potinho interrogado, de 6 pratos, de 2 tigelas, de uma peça que poderá ser uma tacinha e de 2 possíveis taças.

As bilhas seriam usadas para armazenar alimentos líquidos. Os pratos eram usados para servir à mesa ou para comer e, no caso de exemplares de maiores dimensões, podiam ser de uso comunitário. Os jarrinhos, os púcaros e os potinhos teriam utilizações semelhantes, podendo servir para se beber, em uso individual, ou para servir líquidos, com uso, possivelmente, coletivo (Bugalhão e Coelho, 2017, p. 118-126).

No que respeita a cerâmicas de armazenamento e transporte há 1 talha e um pote. As talhas eram usadas para o armazenamento de alimentos líquidos, ou de cereais. O pote funcionava de forma semelhante à talha (Bugalhão e Coelho, 2017, p. 124-131). Há quem coloque a hipótese de os potes serem cobertos por testos (Fernandes, 2012, p. 331).

Observa-se que a maior concentração de cerâmica comum vem da área A, num total de 57 fragmentos cerâmicos. Verifica-se que esta é a zona de onde mais material arqueológico saiu, como já constatado. Da área B saíram 26 fragmentos. Da área C foram exumados 5 , zona de onde saíram menos materiais, facto também já constatado. E da área C/B saiu 1 fragmento cerâmico.

No que respeita à origem das cerâmicas comuns destaca-se o que é designado como Local/Regional, querendo isso dizer, que contendo uma matriz quartzo-micácea, não muito depurada, com grãos de uma pequena média dimensão, com matriz geológica atribuível a produções com origem no vale do Rio Tejo, sendo impossível restringir mais geograficamente, ou procurar mesmo centros produtores, com um total de 211 fragmentos cerâmicos. Existe apenas um bojo atribuído a produções de barro vermelho, tratando-se de cerâmicas não vidradas de uso doméstico, com uma diversidade formal bastante ampla, o qual deverá tratar-se de uma produção Lisboeta (Castro et all, 2017, p. 1742).

No que toca às cozeduras a maioria delas, mais con- cretamente 147 fragmentos, apresentam uma cozedura oxidante. Apenas 2 fragmentos possuem uma cozedura oxidante-redutora. Com cozedura redutora existem 16 fragmentos. Com cozedura redutora-oxidante existem 45 fragmentos. Ou seja, ocorre um predomínio de pastas com tons vermelhos, ou alaranjados, em detrimento das que possuem cores como cinzento ou castanho-escuro. Isso sugere um elevado grau de qualidade nos fornos onde as peças foram cozidas, com um profundo controlo da entrada de oxigénio no interior da câmara de cozedura.

\subsection{Faiança}

A faiança, que corresponde a $14 \%$ do conjunto, trata-se do segundo grupo com maior dimensão. É assim um grupo constituído por 43 fragmentos e, pelo menos, 11 indivíduos.

Existe uma maior concentração de faianças na área A, num total de 29 fragmentos. A área B contém 4 fragmentos e a área $C$ um total de 6 fragmentos. Contabilizam-se 4 fragmentos dos quais se desconhece a área. Destaca-se a área C que, quanto à faiança, contraria a tendência que registava como local com menor número de espólio.

A forma mais representada é a do prato, num total de 5 indivíduos. Destaca-se a existência de 3 escudelas, assim como de 35 fragmentos classificados como indeterminados.

Em relação ao acabamento das faianças, ou seja, ao esmalte, registam-se as seguintes cores: azul sobre branco; azul sobre azul e azul e vináceo, sendo que estas colorações correspondem às habituais em contextos modernos. Destaca-se o azul sobre branco com um total de 33 fragmentos. Sem decoração estão apenas presentes um total de 8 fragmentos, bem como apenas um fragmento de cor azul sobre azul, de estilo berretino (Bercero e Alaix, 2010), e um decorado a azul e vináceo, com temas barroquizantes,. A decoração de muitos dos fragmentos, num total de 26 , foi difícil de precisar, dado o estado de conservação em que se encontravam, sendo dados como motivos indeterminados. Destacam-se os motivos vegetalistas, num total de 7 fragmentos, sobretudo no tema de pétalas de malmequeres (Casimiro, 2013).

Segue-se a decoração com apenas uma banda azul no exterior e motivos vegetalistas no interior, $\mathrm{da}$ qual foram exumados 3 fragmentos.

Regista-se ainda, nas decorações com azul, a existência de um fragmento com decoração em motivo Berettino (Bercero e Alaix, 2010), dois fragmentos 
com círculos concêntricos no fundo, dois fragmentos com motivos compósitos e dois apenas com uma linha simples no interior.

Por fim, surge um fragmento com decoração de motivos barrocos, com a representação de aranhões e pêssegos, com o emprego das cores azul e vináceo sobre fundo branco.

A análise crono-estilística teve por base os trabalhos de Tânia Casimiro (2013) e de Anabela de Sá (2012). Assim sendo, as faianças em estudo inserem-se, no que respeita à decoração em dois tipos o A e o D1, tipos esses que não são fáceis de discernir um do outro neste caso dado que o espólio se encontra bastante fragmentado.

O tipo A caracteriza-se pelas bandas junto ao bordo e por conter círculos concêntricos e motivos vegetalistas como decoração (Sá, 2012, p. 966). O tipo Di contém como principal motivo de decoração bandas geométricas de cor azul (Sá, 2012, p. 968). Esses tipos decorativos encontram-se datados do primeiro quartel do século XVII (Sá, 2012, p. 973). Em termos cronológicos peças com decorações com motivos geométricos e vegetalistas enquadram-se na denominada Fase IV, balizada entre 1635-166o, (Casimiro,2013, p.350). A fase V, datada de 1660-1700, caracteriza-se pelas decorações compósitas, mas também pela difusão por camadas mais modestas, neste caso destaca-se uma peça que contém uma decoração barroca (aranhões e pêssegos), datada, tendo em conta o autor já citado, da última década do século XVII (Casimiro, 2013, p. 362-363). A fase VI, de 1700 a 1766, caracteriza-se por decorações em linhas concêntricas e por peças brancas (Casimiro, 2013, p. 364).

Assim, é possível balizar o conjunto de faianças, a nível decorativo, entre o primeiro quartel do século XVII e meados do século XVIII.

A maioria das faianças, mais concretamente 41 fragmentos, têm origem em Lisboa. Os outros 2 não foi possível determinar com certeza a sua origem dado o seu mau estado de conservação.

\subsection{Porcelanas}

Oriundas da China, as porcelanas são o material mais escasso de todo o espólio estudado constituindo $3 \%$ do total. Efetivamente, neste sítio arqueológico, regista-se a presença de 9 fragmentos resultando em, pelo menos, 5 indivíduos. Estas concentram-se sobretudo na área $\mathrm{A}$, num total de 7 fragmentos. $\mathrm{A}$ área B relevou 2 fragmentos. Não foi encontrada qualquer porcelana na área $\mathrm{C}$.
As formas parecem concentrar-se em pratos com pé anelar, contudo a maioria das formas não são passiveis de classificar pelo estado muito fragmentado do contexto, sendo possível balizar o conjunto das porcelanas sobretudo do século XVII.

As porcelanas em conjunto com as faianças indicam, entre muitas outras coisas, a presença, não propriamente de elites com grande poder económico, mas de populações que possuíam condições financeiras para adquirirem pequenas peças, algo comprovado com o baixo número de indivíduos de porcelana. Como defendido por alguns autores quando afirmam que a compra de porcelanas não era exclusiva de elites (Henriques, 2012, p.930).

\subsection{Azulejos}

Foram exumados um total de 40 fragmentos de azulejos na escavação da Torre Sineira da Igreja Matriz. Destaca-se o facto de a maioria vir da área $\mathrm{A}$, num total de 32. Da área B saíram 6 e 2 da área C.

A policromia da coleção de azulejos é variada, aparecendo as seguintes cores: azul; branco; verde e azul e branco e castanho. A cor com maior número de exemplares é a branca, 15 fragmentos. Destaca-se cor a verde com 10 fragmentos. Com a cor azul existem 7 fragmentos. Com a policromia azul e branco existem 2 fragmentos. Contendo a policromia azul, branco e castanho existem dois fragmentos de azulejo. Esses últimos destaca-se por ser o único importado, tratando-se de um azulejo hispano-mourisco executado segundo a técnica de aresta, produzido, possivelmente, em oficinais sevilhanas. Os exemplares feitos nessa técnica situam-se cronologicamente no segundo quartel do século XVI (Bargão, Ferreira e Silva,2017, p.1786).

Seria inverosímil presumir que estes fossem parte da decoração do exterior da torre. Isso deve-se ao facto de estratigraficamente estes se encontrarem em camadas anteriores à construção da Torre Sineira. Os que foram recolhidos nas áreas exteriores à estrutura $\mathrm{T}$, nas áreas $\mathrm{B}$ e $\mathrm{C}$, não indicam que esta estivesse forrada por eles, por diversos motivos. Em primeiro lugar um dos azulejos da área C data, na sua produção, da primeira metade do século XVI; em segundo lugar o número em que aparecem é quantitativamente bastante baixo; em terceiro lugar encontram-se associados a ossários e a esqueletos. Contudo tem de se colocar a hipótese de grande parte dos azulejos fossem parte de um rodapé que a igreja poderia ter, destruído aquando da construção 
da torre sineira. Tal facto parece ser verosímil pelo facto de na sua maioria, os fragmentos com origem na área $\mathrm{A}$ se encontrarem em camadas anteriores à edificação da torre.

\subsection{Espólio não cerâmico}

Destaca-se uma grande quantidade de pregos encontrados, com um total de 42 na área $\mathrm{A}, 16$ na área $B, 3$ na área C. Destacar que os encontrados nas áreas $\mathrm{B}$ e C estavam dispersos, enquanto os da área A estavam associados a esqueletos, situação que aparenta ser coeva com uso de caixões.

A nível de numismas destacam-se duas moedas em bronze, uma associada ao Esqueleto XII, área A; e outra retirada de terras remexidas, tratando-se ambas de dois ceitis do reinado de D. João II (1455-1495). $\mathrm{Na}$ área $\mathrm{B}$ foram exumadas duas moedas, ambas correspondendo a um real e meio, uma encontrava-se associada ao Esqueleto I, datada de 1712, ou seja, do reinado de $\mathrm{D}$. João $\mathrm{V}$, enquanto a outra estava associada ao Esqueleto II, estando datada do reinado de D. Afonso VI (Oliveira, 2018, p. 10-13)

$\mathrm{Na}$ área A foi encontrada uma conta em osso com perfuração central, assim como mais duas na área B, também em osso, sendo uma delas alongadas, esta com decoração anelar. Estes materiais poderão tratar-se de evidências de colares ou terços dado o seu contexto (Oliveira, 2018, p. 10-11), situação reforçada pela forma circular e lisa da outra conta recolhida na área B.

Destacam-se os alfinetes exumados, possivelmente em bronze, um sem cabeça localizado perto do Esqueleto II, e um completo na camada 2, ambos na área $\mathrm{B}$. Na área $\mathrm{C}$ foi encontrado também um alfinete em bronze sem cabeça.

$\mathrm{Na}$ área $\mathrm{A}$ foi exumado um brinco, associado ao Esqueleto VIII, cujo sexo desconhecemos, em metal, em forma de lágrima, com uma pérola branca. Esta estava ladeada pelos negativos de possíveis pedrinhas. Este não continha o sistema de fechar (Oliveira, 2018, p. 10). Esta evidência sugere que se poderá tratar de um individuo do sexo feminino.

Também foram exumados vidros da escavação, contudo pelo facto da informação que se obteria com o seu estudo ser praticamente nula, optou-se por não se proceder ao seu estudo.

\section{CONCLUSÕES}

A escavação revelou uma zona de descarte cerâmico, assim como um cemitério. Destaque para a cerâmica comum enquanto material dominante em termos estatísticos. Contudo, são as faianças e as porcelanas que permitem tirar conclusões mais prementes sobre os habitantes de Loures. As faianças foram produzidas quase todas em Lisboa, algo compreensível pela proximidade à dita cidade. As porcelanas, não sendo indicador de elites, atestam que seriam consumidas um pouco por todas as classes sociais.

Dos materiais os azulejos poderiam ser os que possuíam uma associação direta com a igreja. Algo que não sendo totalmente verdade, também não deixa de ser uma impossibilidade, pelo facto de existir uma concentração na área onde foi implantada a Torre. Essa situação pode ser explicável com a destruição parcial de um possível rodapé que o exterior da Igreja poderia possuir. Contudo um grupo de azulejos não pertenceriam à igreja, nomeadamente um hispano-mourisco, de aresta, que foi lá descartado, azulejos estes que surgem habitualmente associados a contextos habitacionais.

Apesar dos resultados, estes permitem levantar algumas questões. Poderá parte do espólio estar relacionado com as seis casas mandadas construir na primeira metade do século XVII? Qual a será a verdadeira dimensão e efetiva diacronia do cemitério? No que respeita a dados obtidos em relação ao cemitério, ressalvando que o objetivo principal não era um estudo aprofundado deste, destaca-se a sua aparente cronologia lata, pelo menos entre o século $\mathrm{XV}$ e o XVIII. A grande quantidade de pregos associados a esqueletos leva-nos a crer que estes foram inumados dentro de caixões, já a presença de alfinetes em bronze, associados a certos esqueletos, pode significar o envolvimento do corpo do defunto numa mortalha ou sudário.

\section{BIBLIOGRAFIA}

ARCELIN, P.; TUFFREAU-LIBRE M., ed. (1998) - Protocole de quantification des céramiques. In La quantification des céramiques. Conditions et protocole, Actes de la table ronde du Centre archéologique européen du Mont Beauvray. Glux-en-Glenne: centre archéologique européen du Mont Beauvray, pp. 141-157.

BARGÃO, André; FERREIRA, Sara; SILVA, Rodrigo Banha da (2017) - Policromias e padrões: azulejos "de aresta" e "de corda-seca” do Palácio dos Condes de Penafiel, Lisboa (Sé- 
culos XV-XVI). In Arqueologia em Portugal 2017-Estado da Questão. Lisboa: Associação dos Arqueólogos Portugueses, pp. 1781-1794.

BERCERO, Julia Beltrán; ALAIX, Núria Miró I (2010) - El comerç de cerâmica a Barcelona als segles XVI-XVII: Itàlia, França, Portugal; els tallers del rin i Xina. Quarhis. Barcelona. Época II, no 6, pp. 14-91.

BUGALHÃO, Jacinta; COELHO, Inês (2017) - Cerâmica Moderna de Lisboa: Proposta Tipológica. In I Encontro de Arqueologia de Lisboa: Uma Cidade em Escavação. Lisboa: Centro de Arqueologia de Lisboa / Departamento de Património Cultural / Direção Municipal de Cultura / Câmara Municipal de Lisboa, pp. 106-146.

CASIMIRO, Tânia (2013) - Faiança portuguesa: datação e evolução crono-estilística. Revista Portuguesa de Arqueologia. Lisboa. Volume 16, pp. 351-367.

CASTRO, Anabela; PAULA, Nuno; TORRES, Joana; CURADO, Tiago; TEIXEIRA, André (2017) - Evidências de produção oleira nos séculos XVI e XVII no largo das Olarias, Mouraria (Lisboa). In ARNAUD, J. M. e MARTINS, A. (coords.) Arqueologia em Portugal 2017 - Estado da Questão. Lisboa: Associação dos Arqueólogos Portugueses, pp. 1731-1749.

FERNANDES, I. (2012) - A louça preta em Portugal: estudo histórico, modos de fazer e de usar. Tese de Doutoramento em História, Especialidade em Idade Contemporânea, Braga, Instituto de Ciências Sociais / Universidade do Minho.

HENRIQUES, José. (2012) - Do Oriente para o Ocidente: contributo para o conhecimento da porcelana chinesa nos quotidianos da época moderna. Estudo de três contextos arqueológicos de Lisboa. In TEIXEIRA, André; BETTENCOURT, José, eds. - Velhos e Novos Mundos: Estudos de Arqueologia Moderna. Lisboa: CHAM/Faculdade de Ciências Sociais e Humanas da Universidade Nova de Lisboa e Universidade dos Açores. Volume 2, pp. 919-932.

LEAL, Joaquim José (1909) - Admiravel Egreja Matriz de Loures. Lisboa: Typographia do Commercio.

OLIVEIRA, Ana Cristina (2018) - Notas sobre a intervenção arqueológica na zona envolvente da Igreja Matriz de Loures: Confirmações e Novidades. In Colóquio Igreja de Santa Maria de Loures: Descodificar o Passado, Projetar o Futuro. Loures, pp. 1-26.

OLIVEIRA, Ana Cristina; SILVA, Ana Raquel e ESTÊVÃO, Florbela (1999) - Património edificado do Conselho de Loures. In Catálogo da Exposição "O Medieval e o Moderno em Loures - Viagens pelo Património”. Loures: Câmara Municipal de Loures e Museu Municipal de Loures, pp. 47-67.

SÁ, Anabela (2012) - Elementos para a caracterização da faiança portuguesa do século XVII: a tipologia de Pendery aplicada à realidade da Casa do Infante (Porto). In TEIXEIRA, André; BETTENCOURT, José, eds. - Velhos e Novos Mundos: Estudos de Arqueologia Moderna. Lisboa: CHAM / Faculdade de Ciências Sociais e Humanas da Universidade Nova de Lisboa e Universidade dos Açores. Volume 2, pp. 963-974. 


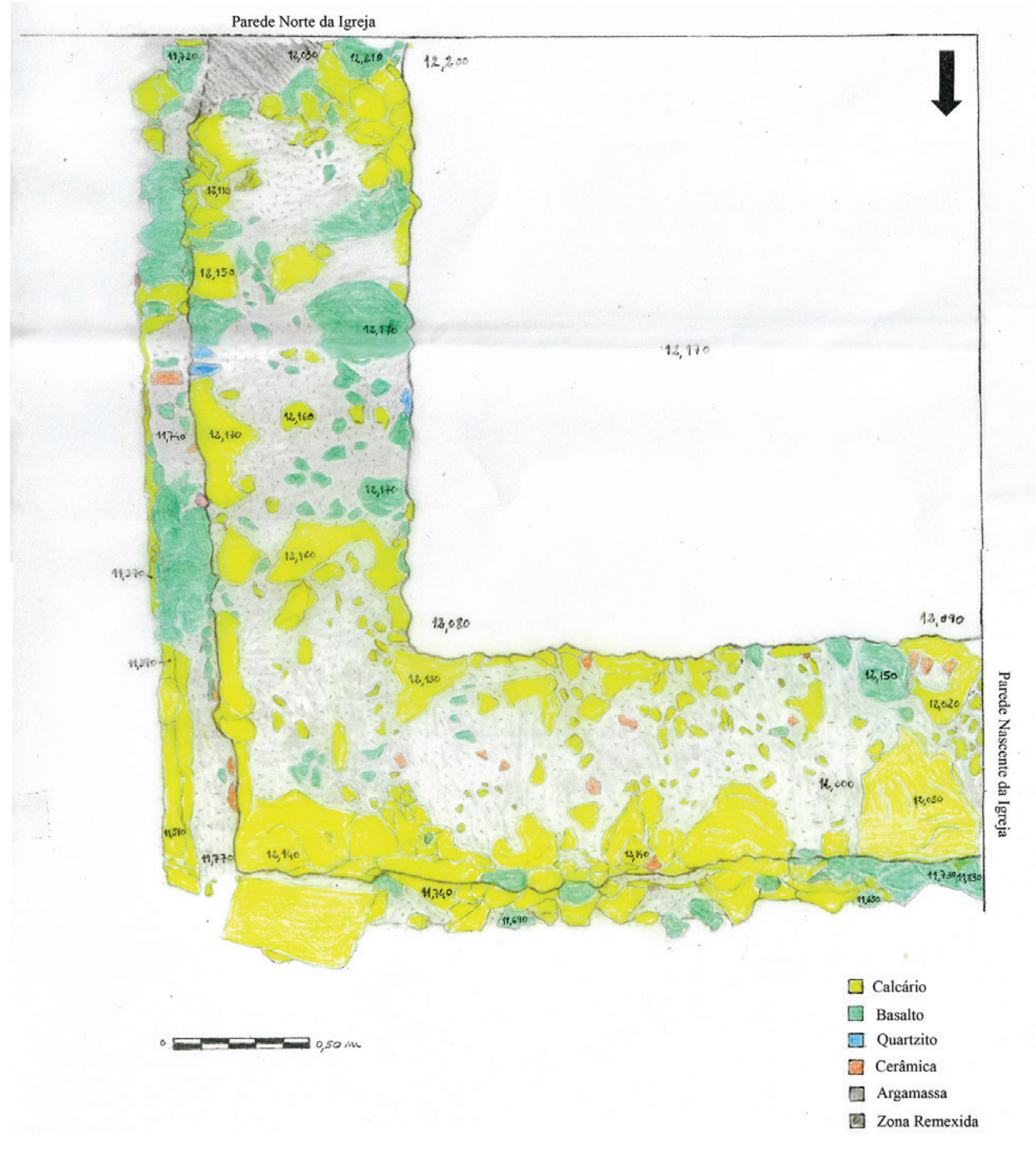

Figura 1 - Planta geral da estrutura T, correspondente aos restos da torre sineira. Museu Municipal de Loures. 


\begin{tabular}{|c|c|c|c|c|c|c|c|c|c|c|}
\hline \multicolumn{11}{|c|}{ NMI total por forma e área } \\
\hline & & \multicolumn{2}{|c|}{ Área A } & \multicolumn{2}{|c|}{ Área B } & \multicolumn{2}{|c|}{ Área C } & \multicolumn{2}{|c|}{ Sem Área } & \multirow{2}{*}{$\begin{array}{l}\text { NMI } \\
\text { Tota }\end{array}$} \\
\hline & Forma & NMI & Total & NMI & Total & $\mathrm{NMI}$ & Total & NMI & Total & \\
\hline \multirow{18}{*}{$\begin{array}{c}\text { Cerâmica } \\
\text { Comum }\end{array}$} & Alguidar & 1 & \multirow{18}{*}{16} & & \multirow{18}{*}{6} & & \multirow{18}{*}{2} & & \multirow{18}{*}{48} & \multirow{23}{*}{88} \\
\hline & Pote & 1 & & & & & & & & \\
\hline & Tacho & 1 & & & & & & 2 & & \\
\hline & Jarrinha & 1 & & & & & & 2 & & \\
\hline & Prato & 1 & & & & & & 5 & & \\
\hline & Indeterminado & 7 & & 3 & & 2 & & 13 & & \\
\hline & Potinho & 4 & & 1 & & & & 6 & & \\
\hline & Panela & & & 1 & & & & 6 & & \\
\hline & Taça? & & & 1 & & & & & & \\
\hline & Bacia & & & & & & & 1 & & \\
\hline & Panela? & & & & & & & 2 & & \\
\hline & Potinho? & & & & & & & 1 & & \\
\hline & Púcaro & & & & & & & 2 & & \\
\hline & Talha & & & & & & & 1 & & \\
\hline & Tigela & & & & & & & & & \\
\hline & Tacinha? & & & & & & & 1 & & \\
\hline & Tacho/Panela? & & & & & & & 3 & & \\
\hline & Tacho? & & & & & & & 1 & & \\
\hline \multirow{3}{*}{ Faiança } & Escudela & 1 & \multirow{3}{*}{7} & 1 & \multirow{3}{*}{2} & & & & \multirow{3}{*}{2} & \\
\hline & Prato & 4 & & & & & & 1 & & \\
\hline & Indeterminada & 2 & & 1 & & & & 1 & & \\
\hline \multirow{2}{*}{ Porcelana } & Prato & 2 & \multirow{2}{*}{5} & & & & & & & \\
\hline & Indeterminada & 3 & & & & & & & & \\
\hline
\end{tabular}

Tabela 1 - Contabilização geral do número mínimo de indivíduos por fabrico, forma eárea de intervenção.

\begin{tabular}{|c|c|c|c|c|}
\hline & \multicolumn{4}{|c|}{ Quadro síntese dos azulejos } \\
\hline & Cores & Quantificação & $\begin{array}{c}\text { Total por } \\
\text { área }\end{array}$ & TOTAL \\
\hline \multirow{4}{*}{ Área A } & Azul & 7 & \multirow{4}{*}{32} & \multirow{9}{*}{40} \\
\hline & Azul e branco & 1 & & \\
\hline & Branco & 15 & & \\
\hline & Verde & 9 & & \\
\hline \multirow{3}{*}{ Área B } & Verde & 4 & \multirow{3}{*}{6} & \\
\hline & $\begin{array}{c}\text { Azul, branco e } \\
\text { castanho(Azulejo de } \\
\text { aresta) }\end{array}$ & 2 & & \\
\hline & Indeterminado & 2 & & \\
\hline \multirow{2}{*}{ Área C } & Azul e branco & 1 & \multirow{2}{*}{2} & \\
\hline & Indeterminado & 1 & & \\
\hline
\end{tabular}

Tabela 2 - Contabilização total do número de fragmentos de azulejo recolhidos na intervenção arqueológica da igreja matriz de Loures. 


\section{Porcelana}
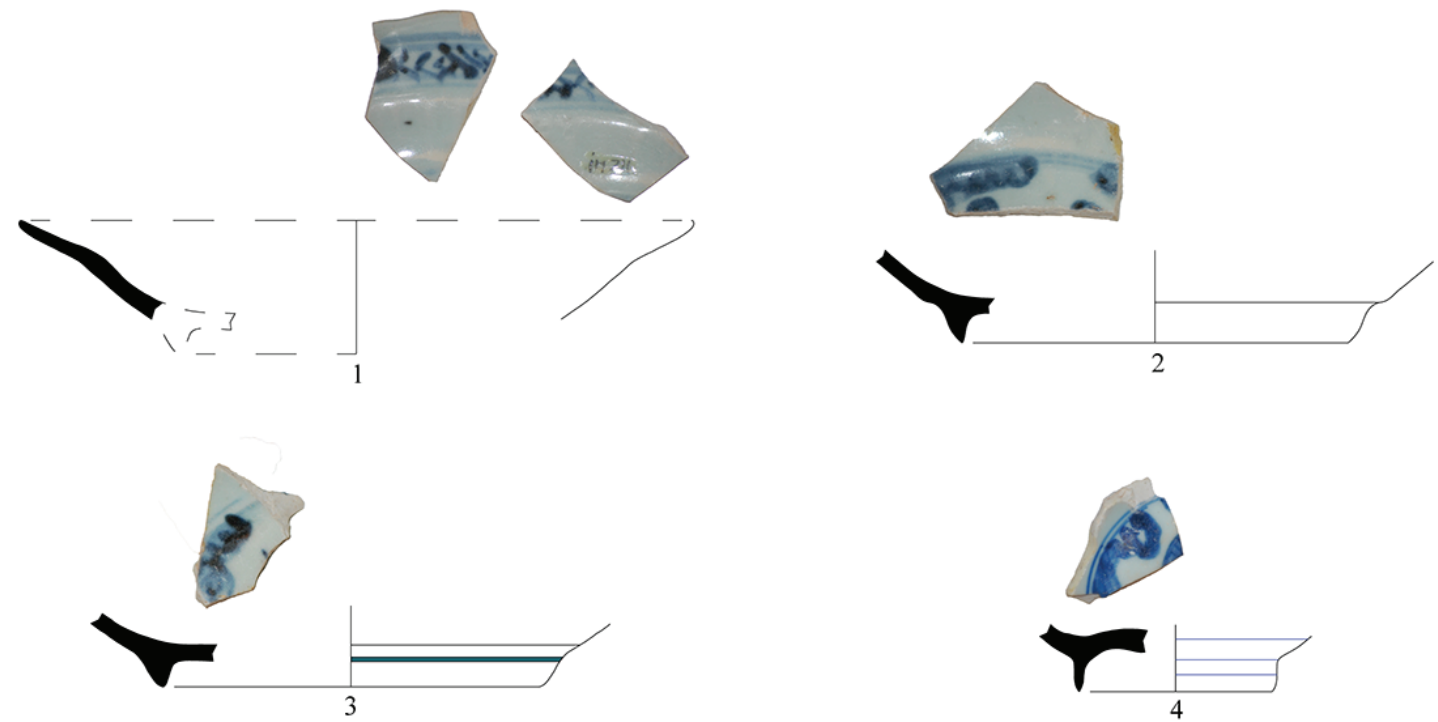

Faiança Portuguesa
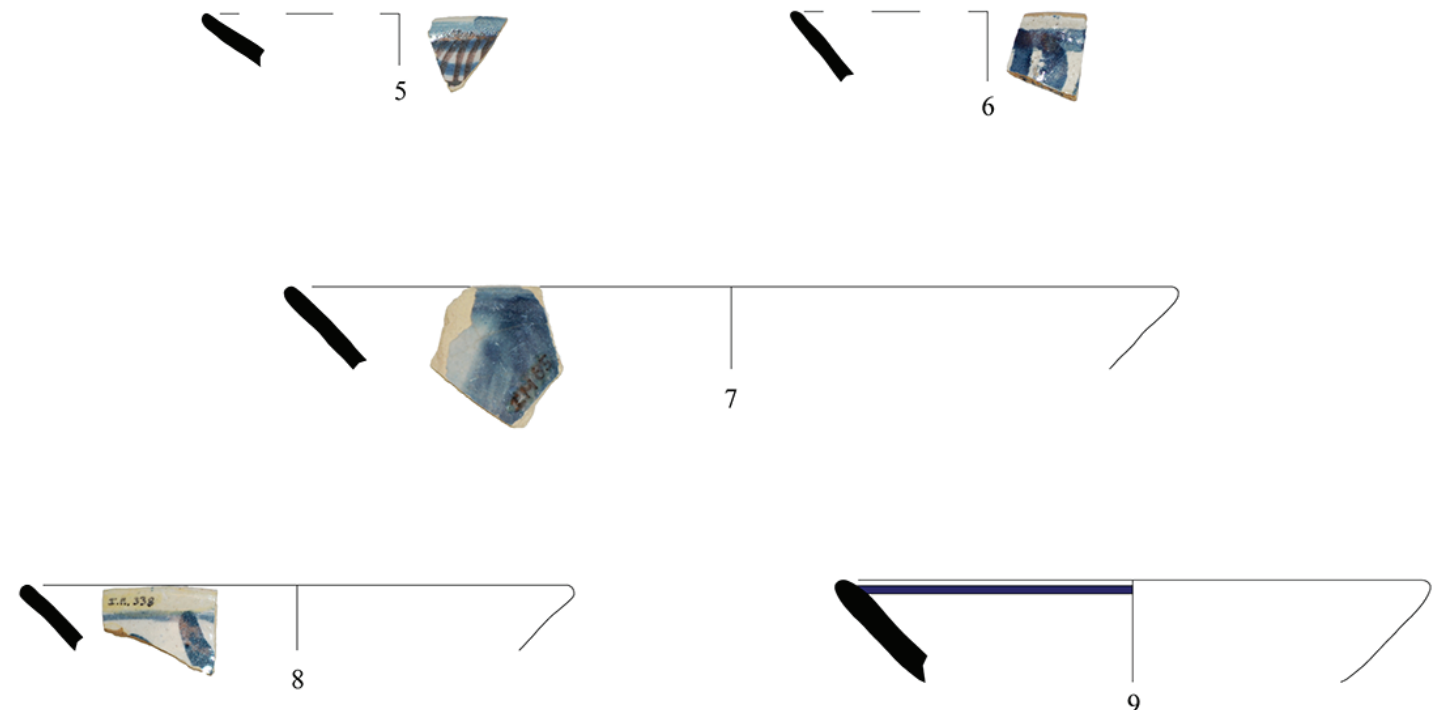

Cerâmica Comum
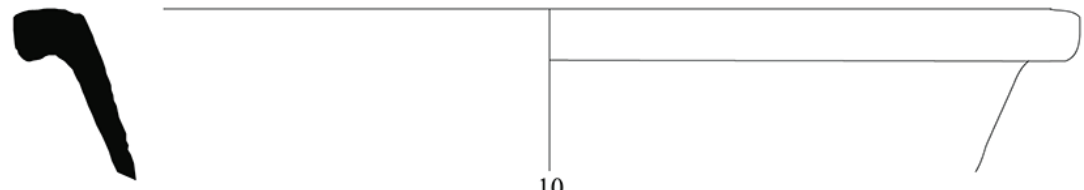

Escala 1:2

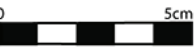

Figura 2-1-3-pratos; 4 - fundo indeterminado; 5- prato com decoração em azul cobalto e manganês; 6-9 - pratos com decoração em azul cobalto; 10 - Bacia. 
Cerâmica Comum
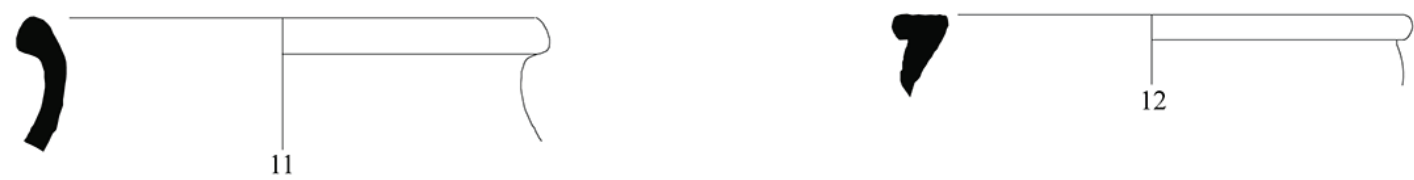

$\int$
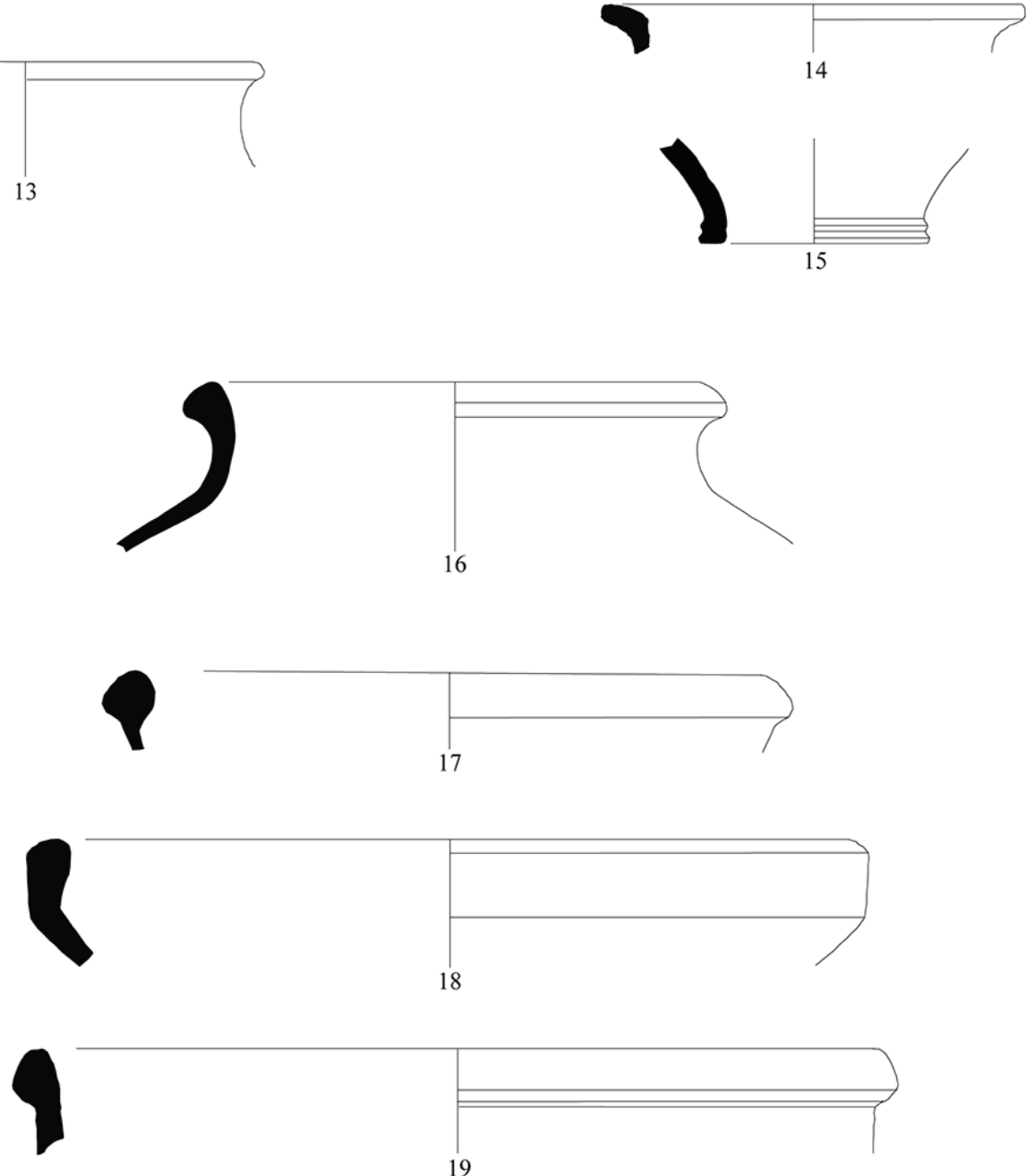

19
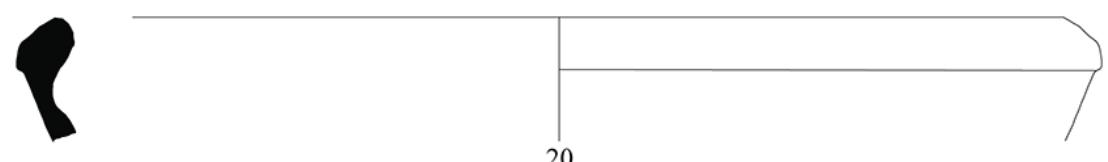

20
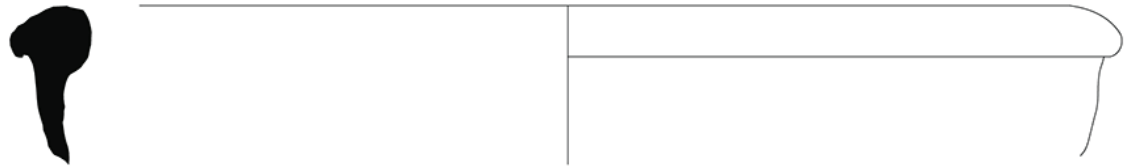

21

Escala 1:2

Figura 3-11-12 - Panelas; 13-15 - Potinhos; 16 - Tacho; 17 - Panela; 18-20 - Tacho; 21 - Panela. 
Cerâmica Comum

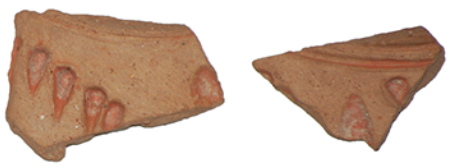

22

Faiança Portuguesa

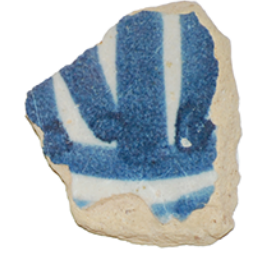

23

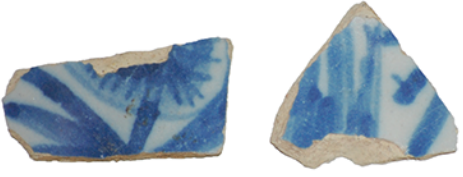

24

Azulejo
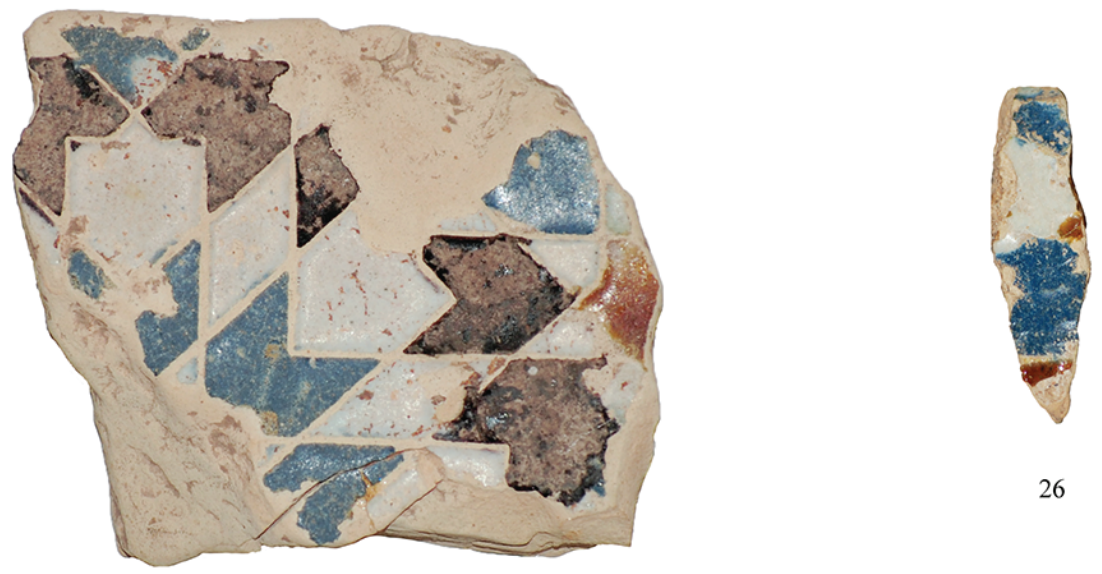

26

25

Numismas

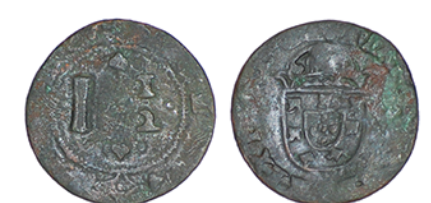

27
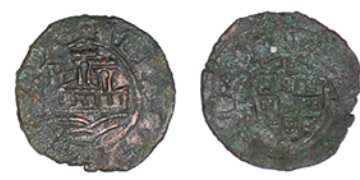

29

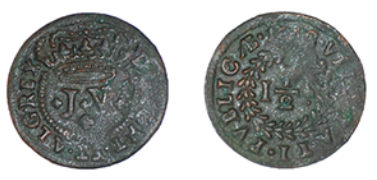

28

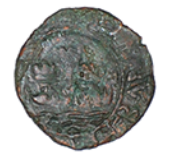

30
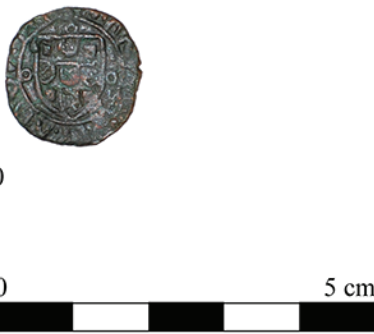

Escala 1:1

Figura 4-22 - Cerâmica comum fina com incisões; 23 - Faiança decorada com motivos de pétalas de malmequer em azul cobalto; 24 - Faiança de motivos vegetalistas em azul cobalto; 25-26 - Fragmentos de azulejo hispano-mourisco; 27 - Real e meio de D. Afonso VI, 1643-1683, associado ao Esq. II; 28 - Real e meio de D. João V, 1712, associado ao Esq. I; 29 - Ceitil de D. João II; 30 - Ceitil de D. João II, associado ao esq. XII. 


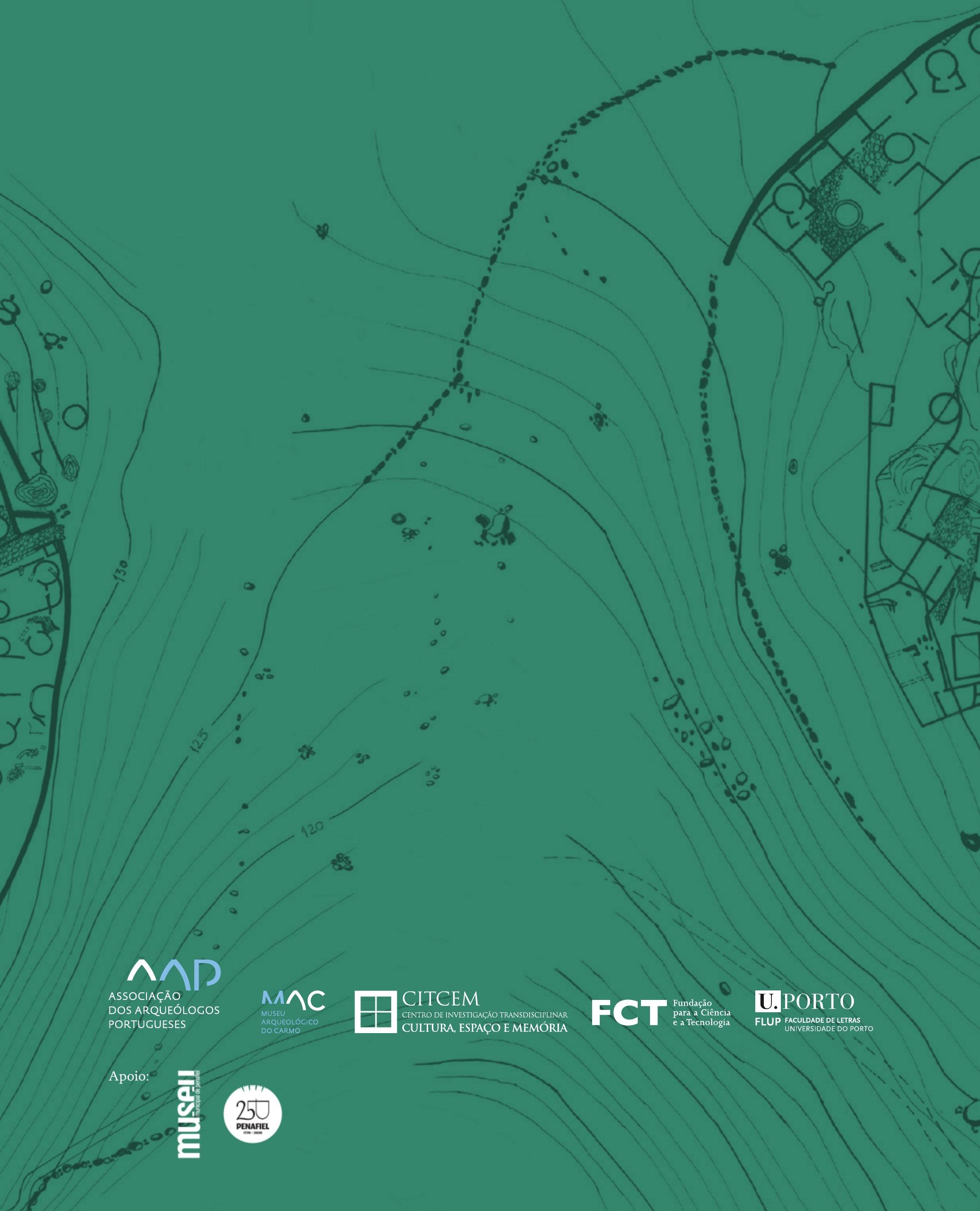

